\title{
Growth and Nutrient Partitioning of Containerized Malus trilobata Schneid. and Acer syriacum Boiss. and Gaill. Under Two Fertigation Regimes
}

\author{
Hala G. Zahreddine ${ }^{1}$ and Daniel K. Struve \\ Department of Horticulture and Crop Sciences, The Ohio State University, \\ 2001 Fyffe Court, Columbus, OH 43210 \\ Salma N. Talhouk \\ Faculty of Agriculture and Food Sciences, The American University of \\ Beirut, P.O. Box 11-0236, Beirut, Lebanon
}

Additional index words. three-lobed apple tree, erect apple, Syrian maple, Lebanese flora, container production, relative growth rate, $\mathrm{N}-\mathrm{P}-\mathrm{K}$ ratios, mineral nutrition, woody ornamentals, nutrient loading

\begin{abstract}
The native flora of Lebanon is threatened. As part of an ex situ conservation strategy, this study was conducted to determine if Malus trilobata (Schneid.) and Acer syriacum (Boiss. and Gaill.), two native Lebanese trees, were amenable to container production. Therefore, these species' growth and nitrogen, phosphorus, and potassium uptake efficiency and distribution under two fertilizer rates were studied. Malus trilobata seedlings were obtained from seeds collected from two mother trees, whereas Acer syriacum seeds were collected from a single tree. Two-year-old seedlings raised from these seeds were planted in 11-L containers in a 3:1 pine bark:compost substrate. Half the seedlings within each source and species were assigned to either 25 or $100 \mathrm{mg} \cdot \mathrm{L}^{-1} \mathrm{~N}$ from 21N-3.1P-5.9K water-soluble fertilizer treatments. Seedlings of both Malus trilobata sources grown under $25 \mathrm{mg} \cdot \mathrm{L}^{-1} \mathrm{~N}$ were taller than those grown at $100 \mathrm{mg} \cdot \mathrm{L}^{-1} \mathrm{~N}$. Nitrogen loading occurred in plants of Malus trilobata under the high fertilizer rate, although total plant $N$, phosphorus, and potassium content was unaffected by fertilizer rate, because larger seedlings had lower nutrient concentrations. There were significant differences in growth among the two Malus trilobata seed sources, but there were no differences in mineral nutrient uptake or nutrient use efficiency. Growth, mineral nutrient uptake, and nutrient use efficiency of Acer syriacum seedlings were unaffected by fertilizer rate. Malus trilobata and Acer syriacum seedlings are amenable to container production. Using container production for these species with subsequent transplanting into managed landscapes might be a viable ex situ conservation method. Further studies are needed.
\end{abstract}

With the end of the civil war in Lebanon in 1990, the demand for low-maintenance landscape plants has been increasing as a result of extensive reconstruction projects. The Lebanese flora was last described by Mouterde (1966, 1970). Since then, the natural vegetation has experienced habitat fragmentation and destruction as a result of tourism and urban expansion, overgrazing, overexploitation of natural resources, and the impact of successive wars. The Lebanese government has been taking in situ conservation measures turning selected threatened habitats into "protected areas" or "nature

Received for publication 21 Mar. 2008. Accepted for publication 15 May 2008.

Salaries and research support provided in part by state and federal funds appropriated to the Ohio Agricultural Research and Development Center, The Ohio State University, and USDA Sustainable Agricultural Development Special Grant 200306231 .

${ }^{1}$ To whom reprint requests should be addressed; e-mail Zahreddine.1@osu.edu depending on the species used and the frequency of fertilizer applications.

In a previous study, we demonstrated that another native Lebanese species, Cercis siliquastrum, Judas tree, was amenable to container production (Zahreddine et al., 2007a). This article describes a similar experiment with two additional native Lebanese species with ornamental traits, Malus trilobata (Schneid.) and Acer syriacum (Boiss. and Gaill.). The two species are not commonly grown in Lebanese nurseries and there are no reports on container production or nutrient partitioning of the species elsewhere.

Malus trilobata, "erect crab" or "threelobed apple tree", belongs to the Rosaceae family. It has an upright habit with horizontal branching and a mature height of $13 \mathrm{~m}$ (Anonymous, 1999). The leaves are maplelike and deeply three-lobed. They turn from orange to red to deep purple in the fall. The tree blooms during April and May producing white flowers and yellow fruits. Hillier and Sons (1973) reports that the species is distributed in the eastern Mediterranean region and northeast Greece adding that the species is comparatively rare and distinct; Mouterde (1966) also reported that it is rare but endemic only to Lebanon. In Lebanon, it is found in the supra-Mediterranean zone at an altitude of 1,000 to $1,500 \mathrm{~m}$ in association with Ostrya, Sorbus, Fraxinus, and Abies species in sandy loam, high $\mathrm{pH}$ soils (Zahreddine et al., 2007b).

Acer syriacum (Boiss. and Gaill.), Syrian maple, is in the Aceraceae family. It reaches $8 \mathrm{~m}$ tall. The leaves are semievergreen to evergreen, glabrous, with three short, acute, or broad lobes. If fall color develops, it ranges from yellow to pink. White to yellow flowers are produced from February to March and the tree develops divergent samaras. It is also native to Syria, Cyprus, and Palestine (Mouterde, 1966). The species grows in the thermo-Mediterranean zone in Lebanon $(0$ to $500 \mathrm{~m}$ altitude). It is reported to be indifferent to soil type but is mainly found in calcareous soils (Anonymous, 1999). Its wood is commonly used for firewood and cabinet making. There is some confusion regarding its taxonomy.

The purpose of this study was to determine the effects of two fertilizer rates on growth, dry weight distribution, mineral nutrient content and distribution, and mineral nutrient uptake efficiency of Malus trilobata and Acer syriacum container-grown seedlings.

\section{Materials and Methods}

A description of plant material and the numbers of seedlings used in this study are given in Table 1. The procedure used in this study is similar to the one used for Cercis siliquastrum (Zahreddine et al., 2007a). However, the Cercis siliquastrum study looked at the effect of two fertilizer rates on the growth and nutrient content of seedlings grown from six different sources or mother trees in Lebanon. Hence, the study was too 
Table 1. Description of the habitat where two Malus trilobata (MT) trees and one Acer syriacum (AS) tree used for seed collection were located in Lebanon and the number of seedlings from each source used in the study.

\begin{tabular}{|c|c|c|c|c|c|}
\hline Species & Source & $\begin{array}{l}\text { Elevation } \\
\text { (m) }\end{array}$ & $\begin{array}{l}\text { Latitude } \\
\text { (N) }\end{array}$ & $\begin{array}{l}\text { Longitude } \\
\text { (E) }\end{array}$ & $\begin{array}{l}\text { Number } \\
\text { of plants } \\
\text { in study }\end{array}$ \\
\hline \multirow[t]{2}{*}{ Malus trilobata } & MT2: Ehden & 1,499 & $34^{\circ} 18.776^{\prime}$ & $035^{\circ} 59.320^{\prime}$ & 80 \\
\hline & MT3: Ehden & 1,457 & $34^{\circ} 18.813^{\prime}$ & $035^{\circ} 59.147^{\prime}$ & 80 \\
\hline Acer syriacum & AS2: Nahr Damour & 43 & $33^{\circ} 41.942^{\prime}$ & $035^{\circ} 29.052^{\prime}$ & 80 \\
\hline
\end{tabular}

long, making it inappropriate to combine it with the current study.

Seeds of Malus trilobata and Acer syriacum were collected from two geographical locations (Ehden and Nahr Damour) in Lebanon in Fall 2001 and brought to The Ohio State University (data not presented) where seed germination trials were carried out. In Spring 2002, germinated seeds were transplanted into 250-XL plastic containers (1.95 L; Nursery Supplies, Fairless Hills, PA) using MetroMix $^{\circledR} 360$ (Scotts Company, Marysville, $\mathrm{OH}$ ) substrate and placed in a heated greenhouse under natural photoperiods. The greenhouse temperatures were set at $25 / 21^{\circ} \mathrm{C}$. The relative humidity averaged $46.6 \pm 2 \%$. Plants were watered as needed to avoid water stress. When seedlings developed two true leaves, they were fertilized once per week with $100 \mathrm{mg} \cdot \mathrm{L}^{-1} \mathrm{~N}$ of $20 \mathrm{~N}-8.3 \mathrm{P}-4.6 \mathrm{~K}$ (2010-10, Peters water-soluble fertilizer; O.M. Scotts Company, Marysville, OH). Plants were overwintered (from November to May) in a minimum heat (minimum temperature greater than $2{ }^{\circ} \mathrm{C}$ ) polyhouse.

In May 2004, the plants (2-year-old seedlings) were removed from the containers, root pruned, transplanted into No. 3 gallon (11 L) Spin-Out ${ }^{\circledR}$ treated containers (1200 Classic; Nursery Supplies), and moved to an outdoor gravel pad. The most vigorous shoot was trained into a central leader by tying it to a $2-\mathrm{m}$ bamboo stake. The plants were placed on $45.7-\mathrm{cm}$ within-row spacing and $2-\mathrm{m}$ between-row spacing. A 3 pine bark: 1 Comtil (by volume) substrate was used. Comtil is a composted municipal sewage sludge from the city of Columbus, $\mathrm{OH}$ (nutrient analysis $0.45-1-0.25$ ) and was used as a slow-release micronutrient source.

Half of the plants from each mother tree or seed source were randomly assigned to one of two $\mathrm{N}$ fertilizer rates: $25 \mathrm{mg}$ or $100 \mathrm{mg} \cdot \mathrm{L}^{-1} \mathrm{~N}$ fertigation from $21 \mathrm{~N}-3.1 \mathrm{P}-5.9 \mathrm{~K}(21-7-7$, Peters Water Soluble Fertilizer; O.M. Scotts Company) applied at $0.5 \mathrm{~L}$ in each of two daily irrigation cycles $\left(1 \mathrm{~L} \cdot \mathrm{d}^{-1}\right.$ total $)$. The fertility treatments were initiated on 1 June and ended on 20 Sept. Plants within a fertility treatment were arranged in a split-plot design with four replications. Each replicate constituted of 10 plants per source and fertilizer level.

An initial harvest of 10 plants per source and fertilizer treatment was done on 12 May 2004 before the start of the experiment and a second harvest on 24 Sept. 2004. At each harvest, height and caliper were measured on the harvested as well as all other trees, whereas leaf area was measured on the 10 randomly harvested trees per source and fertilizer treatment with a LI- 3100 Area meter (LI- COR, Lincoln, NE). Plants were pruned at the root collar, substrate washed from the root systems, plant parts (roots, shoots, and leaves) oven dried at $82{ }^{\circ} \mathrm{C}$ for $96 \mathrm{~h}$, and dry weights recorded. From the 10 plant harvest subsample, three randomly selected individuals from each source and fertilizer rate were selected for nutrient analysis. Leaves, shoots, and roots from these plants were ground to pass through a 20 -mesh screen and 2-g subsamples from each tissue type were sent to the Service Testing And Research Laboratory (STAR Laboratory, OARDC, Wooster, $\mathrm{OH}$ ) for $\mathrm{N}, \mathrm{P}$, and $\mathrm{K}$ nutrient analysis. Total nutrient content of each tissue type was calculated by multiplying the tissue's dry weight by the respective tissue's nutrient concentration. Total plant dry weight or nutrient content was calculated by summing the dry weights or nutrient contents of an individual's stem, roots, and leaves. Leaf, stem, and root relative dry weights, as percentages of total plant dry weight, were calculated. Relative nutrient contents of leaves, stems, and roots were determined similar to the relative dry weights.

Nitrogen use efficiency was calculated by the following equation: $\mathrm{NUE}=\left[\left(\mathrm{TNC}_{2}\right)-\right.$ $\left.\left(\mathrm{TNC}_{1}\right) / \mathrm{TNA}\right] \times 100 \%$ where NUE $=$ nitrogen use efficiency, $\mathrm{TNC}_{2}$ and $\mathrm{TNC}_{1}$ are total plant $\mathrm{N}$ contents in September and May, respectively, and TNA is the total $\mathrm{N}$ applied between May and September. Similarly, P and $\mathrm{K}$ use efficiencies were calculated.

From the dry weights and leaf area data, net assimilation rate (NAR), leaf area ratio (LAR), and relative growth rate (RGR) were calculate NAR, LAR, and RGR, plants within the initial and final harvests were sorted by total plant dry weight and paired by ascending order. Total plant assimilation rates $\left(\mathrm{g} \cdot \mathrm{cm}^{-2} \cdot \mathrm{d}^{-1}\right)$ were calculated as: NAR $=$ $\left(\mathrm{TW}_{2}-\mathrm{TW}_{1}\right) \times\left(\operatorname{Ln} \mathrm{A}_{2}-\mathrm{Ln} \mathrm{A}_{1}\right) /\left[\left(\mathrm{T}_{2}-\mathrm{T}_{1}\right) \times\right.$ $\left.\left(\mathrm{A}_{2}-\mathrm{A}_{1}\right)\right]$; leaf area ratio $\left(\mathrm{g} \cdot \mathrm{cm}^{-2}\right)$ as: $\mathrm{LAR}=$ $\left(\mathrm{A}_{2}-\mathrm{A}_{1}\right) /\left(\mathrm{TW}_{2}-\mathrm{TW}_{1}\right)$; and relative growth rate $\left(\mathrm{g} \cdot \mathrm{g}^{-1} \cdot \mathrm{d}^{-1}\right)$ as $\mathrm{RGR}=\left(\mathrm{Ln} \mathrm{TW}_{2}-\mathrm{Ln}\right.$ $\left.\mathrm{TW}_{1}\right) /\left(\mathrm{T}_{2}-\mathrm{T}_{1}\right)$; where $\mathrm{T}_{1}=$ initial time $(12$ May), $\mathrm{T}_{2}=$ final time (24 Sept.), $\mathrm{TW}_{1}$ and $\mathrm{TW}_{2}$ are total plant dry weight at times 1 and 2 , respectively, and $\mathrm{A}_{1}$ and $\mathrm{A}_{2}=$ leaf area at times 1 and 2 , respectively.

For dry weight analyses, 10 single plant replications were used, whereas mineral nutrient analyses used three single plant replications. Data were analyzed using the one-way analysis of variance procedure calculated according to Evans (1972). To within SPSS (version 12.0; SPSS Institute, Chicago, IL). The linear regression procedure within SigmaPlot (version 9.0) (SPSS, Chicago) was used to develop equations describing plant height during the season; the equations were developed using height data from all the seedlings within a treatment combination.

\section{Results}

Growth and dry weight. Quadratic equations describing Malus trilobata and Acer syriacum height under both fertilizer rates were significant $\left(P<0.001, R^{2}>0.93\right.$, Figs. 1 and 2). Malus height growth was rapid; it doubled between June and September. Growth for Acer syriacum seedlings was not as vigorous; it increased $\approx 25 \%$ between June and September.

The source by fertilizer rate interaction was significant only for Malus trilobata leaf area $(P=0.043$; Table 2$)$. Fertilizer rate did not affect any of the parameters measured for Acer syriacum (Table 2). Fertilizer rate affected only plant height of Malus trilobata; plants were taller at the low fertilizer rate $(168.4 \mathrm{~cm})$ than at the high rate $(130.9 \mathrm{~cm}$; Table 2). Malus trilobata plants from source 2 (MT2) had significantly higher root and total plant dry weights than those from MT3 at both fertilizer rates $(P=0.012$ and $P=0.027$, respectively; Table 2). Root and total plant dry weights were $60.2 \mathrm{~g}$ and $199.6 \mathrm{~g}$, respectively, for MT2 and $34.9 \mathrm{~g}$ and $145.8 \mathrm{~g}$, respectively, for MT3 (Table 2).

There were no significant source by fertilizer rate interaction for relative root, shoot, or leaf dry weight distribution in Malus trilobata plants (Table 3). Fertilizer rates affected only leaf dry weight distribution for Malus trilobata; it was higher at the high fertilizer rate $(14.1 \%$ versus $11.6 \%)$. Fertilizer rate did not affect root, shoot, and leaf dry weight distribution in Acer syriacum plants (Table 3). There were no significant differences between the two Malus trilobata seed sources in root, shoot, and leaf dry weight distribution (Table 3). For both Malus trilobata sources and Acer syriacum, relative shoot dry weight was higher than either leaf or root dry weights at both fertilizer rates, $60 \%$ for Malus trilobata and $43 \%$ for Acer syriacum (Table 3 ).

There was a significant source by fertilizer rate interaction for RGR of Malus trilobata plants $(P=0.025$; Table 4$)$. For both sources, RGR was higher at the low fertilizer rate, but for MT3 plants, the difference was greater than for MT2 plants $\left(0.0049 \mathrm{~g} \cdot \mathrm{g}^{-1} \cdot \mathrm{d}^{-1}\right.$ versus $0.0022 \mathrm{~g} \cdot \mathrm{g}^{-1} \cdot \mathrm{d}^{-1}$, respectively). Fertilizer rate did not affect LAR, NAR, and RGR of Acer syriacum plants, but it did in Malus trilobata (Table 4). Malus trilobata plants grown at the high fertilizer rate had significantly higher LAR and lower NAR (averaging $9.8 \mathrm{~g} \cdot \mathrm{cm}^{-2}$ and $0.0020 \mathrm{~g} \cdot \mathrm{cm}^{2} \cdot \mathrm{d}^{-1}$, respectively) than those grown at the low fertilizer rate (averaging $7.9 \mathrm{~g} \cdot \mathrm{cm}^{-2}$ and $0.0030 \mathrm{~g} \cdot \mathrm{cm}^{2} \cdot \mathrm{d}^{-1}$, respectively). 


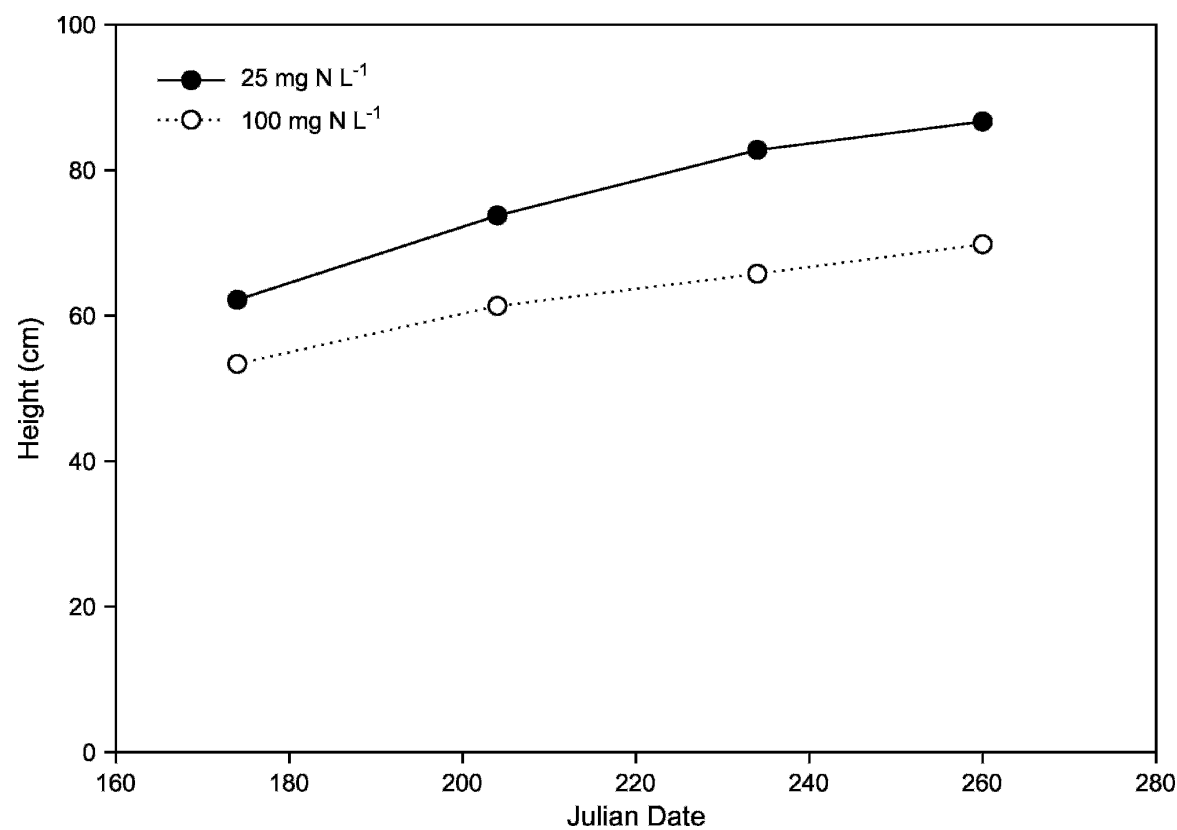

Fig. 1. Height of container-grown Acer syriacum grown under 25 or $100 \mathrm{mg} \cdot \mathrm{L}^{-1} \mathrm{~N}$ from $21 \mathrm{~N}-3.1 \mathrm{P}-5.9 \mathrm{~K}$ water-soluble fertilizer. Each value is the mean of 25 plants per fertilizer rate. Plants were fertilized with 21-7-7 Peters fertilizer. Plant height at $25 \mathrm{mg} \cdot \mathrm{L}^{-1} \mathrm{~N}$ is predicted by the equation: $\mathrm{HT}=-101.75+$ $1.38 \mathrm{X}-0.0025 \mathrm{X}^{2}, R^{2}=0.962, P<0.0001$; whereas plant height at $100 \mathrm{mg} \cdot \mathrm{L}^{-1} \mathrm{~N}$ is predicted by the equation: $\mathrm{HT}=-37.07+0.74 \mathrm{X}-0.0013 \mathrm{X}^{2}, R^{2}=0.952, P=0.038$; where $\mathrm{HT}=$ plant height (in $\mathrm{cm}$ ) and $\mathrm{X}=$ Julian day between 174 and 260. Julian calendar days 174, 204, 234, and 260 refer to the dates when measurements were recorded in June, July, August, and September, respectively.

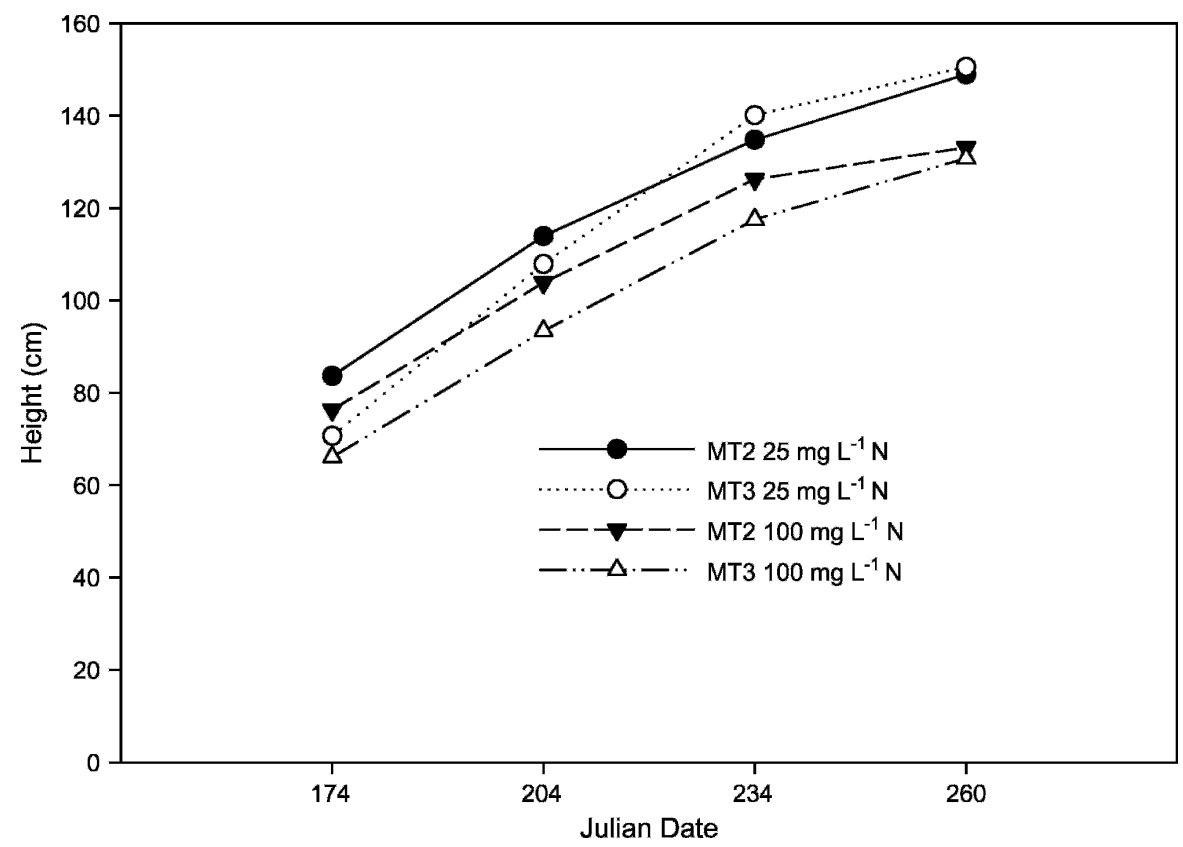

Fig. 2. Height of container-grown Malus trilobata (MT2 and MT3) under 25 or $100 \mathrm{mg} \cdot \mathrm{L}^{-1} \mathrm{~N}$ from $21 \mathrm{~N}-3.1 \mathrm{P}-5.9 \mathrm{~K}$ water-soluble fertilizer. Each value is the mean of 25 plants per fertigation treatment. Plants were fertilized with 21-7-7 Peters water-soluble fertilizer. Plant height at $25 \mathrm{mg} \cdot \mathrm{L}^{-1} \mathrm{~N}$ is predicted by the equation: HT for MT2 plants $=-289.48+3.07 \mathrm{X}-0.0053 \mathrm{X}^{2}, R^{2}=0.944, P=0.045$. HT for MT3 plants $=-490.15+4.74 \mathrm{X}-0.0087 \mathrm{X}^{2}, R^{2}=0.933, P<0.0001$. Plant height at $100 \mathrm{mg} \cdot \mathrm{L}^{-1} \mathrm{~N}$ is predicted by the equation: HT for MT2 plants $=-343.96+3.58 \mathrm{X}-0.0067 \mathrm{X}^{2}, R^{2}=0.939, P=0.028$. HT for MT3 plants $=-238.62+2.41 \mathrm{X}-0.0038 \mathrm{X}^{2}, R^{2}=0.928, P<0.0001$; where HT $=$ plant height (in $\mathrm{cm}$ ) and $\mathrm{X}=$ Julian day between 174 and 260. Julian calendar days 174, 204, 234, and 260 refer to the dates when measurements were recorded in June, July, August, and September, respectively.

Tissue nitrogen concentration, nitrogen content, and relative nitrogen distribution. There were no significant source by fertilizer rate interactions for $\mathrm{N}$ concentration, content, or relative distribution in leaf, shoot, root, and total plant tissues of Malus trilobata (Table 5). Fertilizer rate affected root and total plant $\mathrm{N}$ concentrations; $\mathrm{N}$ concentra- tions were higher at $100 \mathrm{mg} \cdot \mathrm{L}^{-1} \mathrm{~N}$ than at 25 $\mathrm{mg} \cdot \mathrm{L}^{-1} \mathrm{~N}$ for both sources (1.49 versus 1.00 and 1.35 versus 1.12 for MT2 and MT3, respectively; Table 5). Regardless of the tissue type in Malus trilobata, tissue N concentration was higher at the high fertilizer rate than the low fertilizer rate (Table 5). Also, leaf $\mathrm{N}$ concentration was higher than that of stem and root tissue in Malus trilobata at both fertilizer rates. Nitrogen content in leaf and stem tissues was higher at the high fertilizer rate than at the low fertilizer rate in Malus trilobata, but the opposite was true for Acer syriacum plants (Table 5). Relative N distribution in leaf, shoot, and root tissues was unaffected by seed source or fertilizer rate in Malus trilobata or by fertilizer rate for Acer syriacum. In Malus trilobata, shoot tissue had the greatest relative $\mathrm{N}$ content, whereas in Acer syriacum, it was higher in shoot tissue at the low fertilizer rate but higher in leaf tissue at the high fertilizer rate (Table 5).

Tissue phosphorus concentration, phosphorus content, and relative phosphorus distribution. Neither fertilizer rate nor source affected $\mathrm{P}$ concentration or content or its relative distribution in leaf, shoot, and root tissues in Malus trilobata (Table 6). In Acer syriacum, plants under the low fertilizer rate had the most $\mathrm{P}$ in shoot tissue (44\%), whereas at the high fertilizer rate, root tissue contained the most $\mathrm{P}(53 \%)$. In most cases, root $\mathrm{P}$ concentration was higher than that of stem and root tissue at both fertilizer rates in Malus trilobata and Acer syriacum (Table 6).

Tissue potassium concentration, potassium content, and relative potassium distribution. Neither fertilizer rate nor source affected $\mathrm{K}$ concentration or content or its relative distribution in leaf, shoot, and root tissues of Malus trilobata and Acer syriacum (Table 7).

Nutrient uptake and nutrient use efficiencies. For both species, there was no significant source by fertilizer rate interaction for N, P, and K uptake between May and Sept. 2004 or for mineral nutrient use efficiency (Table 8). Fertilizer rate affected potassium use efficiency in Malus trilobata; it was higher at the low fertilizer rate than the high rate ( $41.4 \%$ versus $22.7 \%$, respectively). There were no significant differences between the Malus trilobata seed sources for $\mathrm{N}$, P, and $\mathrm{K}$ uptake and use efficiencies (Table 8). Fertilizer rates did not affect N, $\mathrm{P}$, or $\mathrm{K}$ use efficiencies in Acer syriacum (Table 8).

Nitrogen-phosphorus-potassium ratios. At the high fertilizer rate, the ratio of $\mathrm{N}$ in whole plant tissue was greatest and $\mathrm{P}$ was always the least; but, at the low fertilizer rate, the relative $\mathrm{K}$ content was greatest and $\mathrm{P}$ was the least (Table 9). The ratio of $\mathrm{N}-\mathrm{P}-\mathrm{K}$ in whole plant tissues (relative to P) of MT2 plants was 5.7-1-6.8 at the low fertilizer rate and 7.7-1-5.5 at the high fertilizer rate (Table 9). In plants from MT3, the ratio of $\mathrm{N}$ to $\mathrm{K}$ was lower at the low fertilizer rate and nearly equal at the high fertilizer rate. In Acer syriacum, the ratio of $\mathrm{N}$ to $\mathrm{K}$ was lower at both fertilizer rates (Table 9). 
Table 2. Height, caliper, root, shoot, leaf and total plant dry weights, shoot/root ratio, and leaf area of seedlings raised from two Malus trilobata trees and one Acer syriacum tree when grown under either 25 or $100 \mathrm{mg} \cdot \mathrm{L}^{-1} \mathrm{~N}$ water-soluble fertilizer.

\begin{tabular}{|c|c|c|c|c|c|c|c|c|c|}
\hline \multirow[b]{2}{*}{ Species } & \multirow{2}{*}{$\begin{array}{l}\text { Fertilizer } \\
\left(\mathrm{mg} \cdot \mathrm{L}^{-1} \mathrm{~N}\right)\end{array}$} & \multirow{2}{*}{$\begin{array}{c}\mathrm{Ht} \\
(\mathrm{cm})\end{array}$} & \multirow{2}{*}{$\begin{array}{l}\text { Caliper } \\
(\mathrm{mm})\end{array}$} & \multicolumn{4}{|c|}{ Dry weights(g) } & \multirow{2}{*}{$\begin{array}{c}\text { Shoot/root } \\
\text { ratio }\end{array}$} & \multirow{2}{*}{$\begin{array}{l}\text { Leaf area } \\
\qquad\left(\mathrm{cm}^{2}\right)\end{array}$} \\
\hline & & & & $\overline{\text { Root }}$ & Shoot & Leaf & Total plant & & \\
\hline \multirow[t]{3}{*}{ MT2 } & 25 & $167.4^{\mathrm{z}}$ & $12.9^{y}$ & 61.6 & 125.8 & 21.4 & 208.9 & 2.04 & 1,316 \\
\hline & 100 & 140.3 & 12.2 & 58.8 & 106.2 & 25.4 & 190.4 & 1.80 & 1,693 \\
\hline & Avg. & 153.8 & 12.6 & 60.2 & 116.0 & 23.4 & 199.6 & 1.92 & 1,504 \\
\hline \multirow[t]{3}{*}{ MT3 } & 25 & 169.5 & 12.5 & 36.7 & 110.0 & 21.2 & 167.9 & 3.00 & 1,459 \\
\hline & 100 & 121.5 & 11.5 & 33.2 & 72.1 & 18.5 & 123.8 & 2.17 & 916 \\
\hline & Avg. & 145.5 & 12.0 & 34.9 & 91.0 & 19.8 & 145.8 & 2.58 & 1,187 \\
\hline \multirow[t]{3}{*}{ AS2 } & 25 & 76.1 & 11.4 & 37.7 & 50.5 & 32.6 & 120.7 & 1.34 & 2,843 \\
\hline & 100 & 77.6 & 11.0 & 33.7 & 55.1 & 35.1 & 123.9 & 1.63 & 3,021 \\
\hline & Avg. & 76.8 & 11.2 & 35.7 & 52.8 & 33.8 & 122.3 & 1.48 & 2,932 \\
\hline ANOVA & \multicolumn{9}{|c|}{$P>\mathrm{F}$ value } \\
\hline \multicolumn{10}{|l|}{ Malus trilobata } \\
\hline Source (S) & & $\mathrm{NS}^{\mathrm{x}}$ & NS & $*$ & NS & NS & $*$ & NS & NS \\
\hline Fertilizer rate $(\mathrm{FR})$ & & $* *$ & NS & NS & NS & NS & NS & NS & NS \\
\hline $\mathrm{S} * \mathrm{FR}$ & & NS & NS & NS & NS & NS & NS & NS & $*$ \\
\hline \multicolumn{10}{|l|}{ Acer syriacum } \\
\hline Fertilizer rate $(\mathrm{FR})$ & & NS & NS & NS & NS & NS & NS & NS & NS \\
\hline
\end{tabular}

${ }^{\mathrm{z}}$ Each value is the mean of 10 individual seedlings within each species and fertilizer.

${ }^{\mathrm{y}}$ Caliper was measured at 1 inch $(2.5 \mathrm{~cm})$ above the root-shoot junction.

${ }_{\mathrm{NS}}, *$, and $* *$ indicate no statistical difference at $\alpha=0.05$ level of significance or statistical difference at $\alpha \leq 0.05$ or $\alpha \leq 0.01$, respectively.

Table 3. Distribution of root, shoot, and leaf dry weights of seedlings raised from two Malus trilobata trees and one Acer syriacum tree when grown under either 25 or $100 \mathrm{mg} \cdot \mathrm{L}^{-1} \mathrm{~N}$ water-soluble fertilizer.

\begin{tabular}{|c|c|c|c|c|}
\hline \multirow[b]{2}{*}{ Species } & \multirow{2}{*}{$\begin{array}{l}\text { Fertilizer } \\
\left(\mathrm{mg} \cdot \mathrm{L}^{-1} \mathrm{~N}\right)\end{array}$} & \multicolumn{3}{|c|}{ Dry weight distribution (\%) } \\
\hline & & Root & Shoot & Leaf \\
\hline \multirow[t]{3}{*}{$\overline{\mathrm{MT} 2}$} & 25 & $29.5^{z}$ & 60.2 & 10.6 \\
\hline & 100 & 30.9 & 55.8 & 13.3 \\
\hline & Avg. & 30.2 & 58.0 & 11.9 \\
\hline \multirow{3}{*}{ MT3 } & 25 & 21.9 & 65.5 & 12.6 \\
\hline & 100 & 26.8 & 58.2 & 14.9 \\
\hline & Avg. & 24.3 & 61.8 & 13.7 \\
\hline \multirow[t]{3}{*}{ AS2 } & 25 & 31.2 & 41.8 & 27.0 \\
\hline & 100 & 27.2 & 44.5 & 28.3 \\
\hline & Avg. & 29.2 & 43.1 & 27.6 \\
\hline ANOVA & & & $P>\mathrm{F}$ value & \\
\hline \multicolumn{5}{|l|}{ Malus trilobata } \\
\hline Source (S) & & $\mathrm{NS}^{\mathrm{y}}$ & NS & NS \\
\hline Fertilizer rate (FR) & & NS & NS & * \\
\hline $\mathrm{S} * \mathrm{FR}$ & & NS & NS & NS \\
\hline \multicolumn{5}{|l|}{ Acer syriacum } \\
\hline Fertilizer rate (FR) & & NS & NS & NS \\
\hline
\end{tabular}

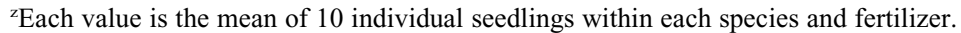

$\mathrm{y}_{\mathrm{NS}},{ }^{*}$, and ${ }^{* *}$ indicate no statistical difference at $\alpha=0.05$ level of significance or statistical difference at $\alpha \leq 0.05$ or $\alpha \leq 0.01$, respectively.

Table 4. Leaf area ratio (LAR), net assimilation rate (NAR), and relative growth rate (RGR) of seedlings raised from two Malus trilobata trees and one Acer syriacum tree when grown under either 25 or $100 \mathrm{mg} \cdot \mathrm{L}^{-1} \mathrm{~N}$ water-soluble fertilizer.

\begin{tabular}{|c|c|c|c|c|}
\hline Species & $\begin{array}{l}\text { Fertilizer } \\
\left(\mathrm{mg} \cdot \mathrm{L}^{-1} \mathrm{~N}\right)\end{array}$ & $\begin{array}{c}\mathrm{LAR} \\
\left(\mathrm{g} \cdot \mathrm{cm}^{-2}\right)\end{array}$ & $\begin{array}{c}\text { NAR } \\
\left(\mathrm{g} \cdot \mathrm{cm}^{-2} \cdot \mathrm{d}^{-1} \times 10^{-3}\right)\end{array}$ & $\begin{array}{c}\text { RGR } \\
\left(\mathrm{g} \cdot \mathrm{g}^{-1} \cdot \mathrm{d}^{-1} \times 10^{-3}\right)\end{array}$ \\
\hline \multirow[t]{3}{*}{ MT2 } & 25 & $7.2^{z}$ & 3.7 & 25.7 \\
\hline & 100 & 10.5 & 2.5 & 23.5 \\
\hline & Avg. & 8.8 & 3.1 & 24.6 \\
\hline \multirow[t]{3}{*}{ MT3 } & 25 & 8.6 & 2.2 & 17.4 \\
\hline & 100 & 9.7 & 1.4 & 12.5 \\
\hline & Avg. & 9.1 & 1.8 & 14.9 \\
\hline \multirow[t]{3}{*}{ AS2 } & 25 & 25.7 & 0.8 & 20.3 \\
\hline & 100 & 27.7 & 0.7 & 19.0 \\
\hline & Avg. & 26.7 & 0.7 & 19.6 \\
\hline ANOVA & \multicolumn{4}{|c|}{$P>\mathrm{F}-$ value } \\
\hline \multicolumn{5}{|l|}{ Malus trilobata } \\
\hline Source (S) & & $\mathrm{NS}^{\mathrm{y}}$ & ** & ** \\
\hline Fertilizer rate (FR) & & $*$ & $* *$ & $* *$ \\
\hline $\mathrm{S} * \mathrm{FR}$ & & NS & NS & * \\
\hline \multicolumn{5}{|l|}{ Acer syriacum } \\
\hline Fertilizer rate (FR) & & NS & NS & NS \\
\hline
\end{tabular}

${ }^{\mathrm{z}}$ Each value is the mean of 10 individual seedlings within each source and fertilizer.

$\mathrm{y}_{\mathrm{NS}}, *$, and $* *$ indicate no statistical difference at $\alpha=0.05$ level of significance or statistical difference at $\alpha \leq 0.05$ or $\alpha \leq 0.01$, respectively.

\section{Discussion}

The lower fertilizer rate, $25 \mathrm{mg} \cdot \mathrm{L}^{-1} \mathrm{~N}$, resulted in greater growth than the high fertilizer rate, $100 \mathrm{mg} \cdot \mathrm{L}^{-1} \mathrm{~N}$, in Malus trilobata seedlings. They were taller; had greater caliper, shoot, root, and leaf dry weights; and higher NAR at the lower fertilizer rate. However, the higher fertilizer rate increased LAR. Similar results were found for Cercis siliquastrum (Zahreddine et al., 2007a). In contrast, Acer syriacum growth was unaffected by fertilizer rate. Therefore, when using $21 \mathrm{~N}-3.1 \mathrm{P}-5.9 \mathrm{~K}$ water-soluble fertilizer, we recommend that both species be fertilized at $25 \mathrm{mg} \cdot \mathrm{L}^{-1} \mathrm{~N}$ rather than 100 $\mathrm{mg} \cdot \mathrm{L}^{-1} \mathrm{~N}$, which would result in a $75 \%$ reduction in fertilizer use without reducing growth. Additional testing is needed to determine the optimum fertilizer rate for these species in container-production systems. The $25 \mathrm{mg} \cdot \mathrm{L}^{-1} \mathrm{~N}$ fertilizer rate is lower than that typically recommended for other containergrown perennial woody species. Malus trilobata growth was vigorous at a lower rate than that reported by others for other genera (Gilliam et al., 1980, 1984; Ingestad, 1979; Jull et al., 1994; Larimer and Struve, 2002; Lumis et al., 2000; Musselwhite et al., 2004; Stubbs et al., 1997; Wright and Niemiera, 1987). For example, red maple growth was greatest at 200 to $400 \mathrm{mg} \cdot \mathrm{L}^{-1} \mathrm{~N}$ (Gilliam et al., 1980; Larimer and Struve, 2002). However, $20 \mathrm{mg} \cdot \mathrm{L}^{-1} \mathrm{~N}$ was optimal for Cupressus arizonica var. glabra 'Carolina Sapphire' (Arizona cypress 'Carolina Sapphire'). In that study, higher fertilizer rates did not affect height and stem diameter, although $\mathrm{N}$ concentration in shoots and leaves increased with increased $\mathrm{N}$ rate (Stubbs et al., 1997). Height growth of Malus trilobata seedlings was similar to that of a container-grown crabapple (Stoven, 2004). Height growth of Acer syriacum was less that than of container-grown Acer 'Autumn Flame' (Larimer and Struve, 2002), not an 
Table 5. Nitrogen concentration and content in leaf, shoot, root, and total plant tissues and nitrogen distribution in leaf, shoot, and root tissues as percent of total plant $\mathrm{N}$ content of seedlings raised from two Malus trilobata trees and one Acer syriacum tree when grown under either 25 or $100 \mathrm{mg} \cdot \mathrm{L}^{-1} \mathrm{~N}$ water-soluble fertilizer.

\begin{tabular}{|c|c|c|c|c|c|c|c|c|c|c|c|c|}
\hline \multirow[b]{2}{*}{ Source } & \multirow{2}{*}{$\begin{array}{l}\text { Fertilizer rate } \\
\left(\mathrm{mg} \cdot \mathrm{L}^{-1} \mathrm{~N}\right)\end{array}$} & \multicolumn{4}{|c|}{ Nitrogen concn $(\%)$} & \multicolumn{4}{|c|}{ Nitrogen content (g) } & \multicolumn{3}{|c|}{ Nitrogen distribution $(\%)$} \\
\hline & & $\overline{\text { Leaf }}$ & Shoot & Root & Total plant & Leaf & Shoot & Root & Total plant & Leaf & Shoot & Root \\
\hline \multirow[t]{2}{*}{ MT 2} & 25 & $2.16^{z}$ & 0.71 & 1.09 & 0.98 & 0.45 & 1.00 & 0.94 & 2.40 & 19 & 42 & 39 \\
\hline & 100 & 2.32 & 1.13 & 1.49 & 1.41 & 0.51 & 1.06 & 0.75 & 2.32 & 22 & 46 & 32 \\
\hline \multirow[t]{2}{*}{ MT 3} & 25 & 2.05 & 0.73 & 1.16 & 1.02 & 0.57 & 0.92 & 0.57 & 2.06 & 28 & 45 & 27 \\
\hline & 100 & 2.27 & 0.90 & 1.49 & 1.26 & 0.80 & 1.10 & 0.63 & 2.53 & 32 & 43 & 25 \\
\hline \multirow[t]{2}{*}{ AS 2} & 25 & 1.29 & 0.83 & 1.39 & 1.09 & 0.46 & 0.50 & 0.38 & 1.35 & 34 & 37 & 28 \\
\hline & 100 & 1.68 & 0.83 & 1.30 & 1.22 & 0.38 & 0.26 & 0.35 & 1.00 & 38 & 27 & 35 \\
\hline ANOVA & \multicolumn{12}{|c|}{$P>\mathrm{F}$ value } \\
\hline \multicolumn{13}{|l|}{ Malus trilobata } \\
\hline Source (S) & & $\mathrm{NS}^{\mathrm{y}}$ & NS & NS & NS & NS & NS & NS & NS & NS & NS & NS \\
\hline Fertilizer rate $(\mathrm{FR})$ & & NS & NS & $*$ & $*$ & NS & NS & NS & NS & NS & NS & NS \\
\hline $\mathrm{S}^{*} \mathrm{FR}$ & & NS & NS & NS & NS & NS & NS & NS & NS & NS & NS & NS \\
\hline \multicolumn{13}{|l|}{ Acer syriacum } \\
\hline Fertilizer rate (FR) & & NS & NS & NS & NS & NS & NS & NS & NS & NS & NS & NS \\
\hline
\end{tabular}

Table 6. Phosphorus concentration and content in leaf, shoot, root, and total plant tissues and $\mathrm{P}$ distribution in leaf, shoot, and root tissues as percent of total plant $\mathrm{P}$ content of seedlings raised from two Malus trilobata trees and one Acer syriacum tree when grown under either 25 or $100 \mathrm{mg} \cdot \mathrm{L}^{-1} \mathrm{~N}$ water-soluble fertilizer.

\begin{tabular}{|c|c|c|c|c|c|c|c|c|c|c|c|c|}
\hline \multirow[b]{2}{*}{ Source } & \multirow{2}{*}{$\begin{array}{l}\text { Fertilizer rate } \\
\left(\mathrm{mg} \cdot \mathrm{L}^{-1} \mathrm{~N}\right)\end{array}$} & \multicolumn{4}{|c|}{ Phosphorus concn $\left(\mu g \cdot g^{-1}\right)$} & \multicolumn{4}{|c|}{ Phosphorus content $(\mathrm{g})$} & \multicolumn{3}{|c|}{ Phosphorus distribution (\%) } \\
\hline & & Leaf & Shoot & Root & Total plant & Leaf & Shoot & Root & $\overline{\text { Total plant }}$ & Leaf & Shoot & Root \\
\hline \multirow[t]{2}{*}{ MT 2} & 25 & $2,056^{z}$ & 964 & 2,341 & 1,634 & 0.04 & 0.13 & 0.25 & 0.42 & 9 & 31 & 60 \\
\hline & 100 & 2,169 & 1,400 & 2,383 & 1,822 & 0.05 & 0.13 & 0.13 & 0.30 & 17 & 42 & 42 \\
\hline \multirow[t]{2}{*}{ MT 3} & 25 & 1,894 & 95 & 1,954 & 1,354 & 0.05 & 0.13 & 0.10 & 0.28 & 18 & 46 & 36 \\
\hline & 100 & 2,175 & 1,178 & 2,511 & 1,639 & 0.07 & 0.14 & 0.11 & 0.32 & 22 & 44 & 34 \\
\hline \multirow[t]{2}{*}{ AS 2} & 25 & 1,408 & 1,922 & 3,375 & 2,102 & 0.05 & 0.12 & 0.10 & 0.26 & 19 & 44 & 37 \\
\hline & 100 & 1,829 & 2,002 & 4,403 & 2,740 & 0.04 & 0.06 & 0.12 & 0.22 & 18 & 29 & 53 \\
\hline ANOVA & \multicolumn{12}{|c|}{$P>\mathrm{F}$ value } \\
\hline \multicolumn{13}{|l|}{ Malus trilobata } \\
\hline Source (S) & & $\mathrm{NS}^{\mathrm{y}}$ & NS & NS & NS & NS & NS & NS & NS & NS & NS & NS \\
\hline Fertilizer rate $(\mathrm{FR})$ & & NS & NS & NS & NS & NS & NS & NS & NS & NS & NS & NS \\
\hline $\mathrm{S} * \mathrm{FR}$ & & NS & NS & NS & NS & NS & NS & NS & NS & NS & NS & NS \\
\hline \multicolumn{13}{|l|}{ Acer syriacum } \\
\hline Fertilizer rate (FR) & & NS & NS & NS & NS & NS & NS & NS & NS & NS & $*$ & $*$ \\
\hline
\end{tabular}

${ }^{\mathrm{z} E a c h}$ value is the mean of three plants for each source and fertilizer rate.

${ }_{\mathrm{NS}}, *$, and $* *$ indicate no statistical difference at $\alpha=0.05$ level of significance or statistical difference at $\alpha \leq 0.05$ or $\alpha \leq 0.01$, respectively.

Table 7. Potassium concentration and content in leaf, shoot, root, and total plant tissues and K distribution in leaf, shoot, and root tissues as percent of total plant $\mathrm{K}$ content of seedlings raised from two Malus trilobata trees and one Acer syriacum tree when grown under either 25 or 100 mg. $\mathrm{L}^{-1} \mathrm{~N}$ water-soluble fertilizer.

\begin{tabular}{|c|c|c|c|c|c|c|c|c|c|c|c|c|}
\hline \multirow[b]{2}{*}{ Source } & \multirow{2}{*}{$\begin{array}{c}\text { Fertilizer rate } \\
\left(\mathrm{mg} \cdot \mathrm{L}^{-1} \mathrm{~N}\right)\end{array}$} & \multicolumn{4}{|c|}{ Potassium concn $\left(\mu \mathrm{g} \cdot \mathrm{g}^{-1}\right)$} & \multicolumn{4}{|c|}{ Potassium content $(\mathrm{g})$} & \multicolumn{3}{|c|}{ Potassium distribution (\%) } \\
\hline & & Leaf & Shoot & Root & Total plant & $\overline{\text { Leaf }}$ & Shoot & Root & Total plant & Leaf & Shoot & Root \\
\hline \multirow[t]{2}{*}{$\overline{\text { MT } 2}$} & 25 & $17,064^{z}$ & 11,883 & 9,698 & 12,143 & 0.35 & 1.66 & 0.84 & 2.85 & 12 & 58 & 30 \\
\hline & 100 & 17,130 & 8,835 & 10,242 & 10,561 & 0.37 & 0.72 & 0.55 & 1.64 & 23 & 44 & 33 \\
\hline \multirow[t]{2}{*}{ MT 3} & 25 & 15,984 & 1,225 & 9,425 & 12,072 & 0.45 & 1.56 & 0.47 & 2.48 & 18 & 3 & 19 \\
\hline & 100 & 17,425 & 11,736 & 1,537 & 12,722 & 0.57 & 1.37 & 0.52 & 2.47 & 23 & 56 & 21 \\
\hline \multirow[t]{2}{*}{ AS 2} & 25 & 10,422 & 13,746 & 15,298 & 13,367 & 0.37 & 0.84 & 0.46 & 1.67 & 22 & 50 & 27 \\
\hline & 100 & 10,043 & 13,798 & 17,620 & 13,920 & 0.22 & 0.42 & 0.47 & 1.11 & 20 & 38 & 42 \\
\hline ANOVA & \multicolumn{12}{|c|}{$P>\mathrm{F}$ value } \\
\hline \multicolumn{13}{|l|}{ Malus trilobata } \\
\hline Source (S) & & $\mathrm{NS}^{\mathrm{y}}$ & NS & NS & NS & NS & NS & NS & NS & NS & NS & NS \\
\hline Fertilizer rate $(\mathrm{FR})$ & & NS & NS & NS & NS & NS & NS & NS & NS & NS & NS & NS \\
\hline S*FR & & NS & NS & NS & NS & NS & NS & NS & NS & NS & NS & NS \\
\hline \multicolumn{13}{|l|}{ Acer syriacum } \\
\hline Fertilizer rate (NFR) & & NS & NS & NS & NS & NS & NS & NS & NS & NS & NS & NS \\
\hline
\end{tabular}

${ }^{\mathrm{z}}$ Each value is the mean of three plants for each source and fertilizer rate.

${ }_{\mathrm{NS}}, *$, and $* *$ indicate no statistical difference at $\alpha=0.05$ level of significance or statistical difference at $\alpha \leq 0.05$ or $\alpha \leq 0.01$, respectively.

unexpected finding because Acer syriacum's mature height is less than 'Autumn Flame'.

There were only two source by fertilizer rate interactions for Malus trilobata seedlings, leaf area and RGR. Fertilizer rate changed the rank order for leaf area of the two Malus sources; at the high rate, leaf area increased in MT2 but decreased in MT3. Both Malus sources had lower RGR at the higher fertilizer rate, but the decrease was greater for MT3 than MT2. There was also a source by fertilizer rate interaction for RGR among six Cercis siliquastrum. For Cercis, four sources had lower RGR at the higher fertilizer rate, one was unchanged, and one had higher RGR (Zahreddine et al., 2007a).

The relative distribution of Malus trilobata's total plant dry weight was altered by fertilizer rate; at the higher fertilizer rate, relatively more dry weight was in leaves and roots and less in shoots, but shoot tissue still represented the greatest relative percentage of total plant dry weight. In contrast, relative shoot dry weight of Cercis siliquastrum (Zahreddine et al., 2007a) and 'Autumn Blaze' red maple (Larimer and Struve, 2002) plants increased with higher $\mathrm{N}$ addition rates. Acer syriacum growth was unaffected by fertilizer rate; it also had the highest relative percentage of total plant dry weight 
Table 8. Nitrogen, $\mathrm{P}$, and $\mathrm{K}$ uptake and mineral nutrient use efficiency of seedlings raised from two Malus trilobata trees and one Acer syriacum tree when grown under either 25 or $100 \mathrm{mg} \cdot \mathrm{L}^{-1} \mathrm{~N}$ watersoluble fertilizer.

\begin{tabular}{|c|c|c|c|c|c|c|c|}
\hline \multirow[b]{2}{*}{ Source } & \multirow{2}{*}{$\begin{array}{c}\text { Fertilizer rate } \\
\left(\mathrm{mg} \cdot \mathrm{L}^{-1} \mathrm{~N}\right)\end{array}$} & \multicolumn{3}{|c|}{$\begin{array}{l}\text { Mineral nutrient } \\
\text { uptake }(\mathrm{g})\end{array}$} & \multicolumn{3}{|c|}{$\begin{array}{l}\text { Mineral nutrient } \\
\text { use efficiency }(\%)\end{array}$} \\
\hline & & $\mathrm{N}$ & $\mathrm{P}$ & $\mathrm{K}$ & $\overline{\mathrm{N}}$ & $\mathrm{P}$ & $\mathrm{K}$ \\
\hline \multirow[t]{2}{*}{$\overline{\text { MT } 2}$} & 25 & $2.24^{z}$ & 0.41 & 2.42 & 10 & 2 & 45 \\
\hline & 100 & 2.17 & 0.29 & 1.21 & 7 & 1 & 18 \\
\hline \multirow[t]{2}{*}{ MT 3} & 25 & 1.78 & 0.25 & 2.20 & 8 & 1 & 38 \\
\hline & 100 & 2.26 & 0.29 & 2.19 & 7 & 1 & 27 \\
\hline \multirow[t]{2}{*}{ AS 2} & 25 & 1.13 & 0.24 & 1.40 & 5 & 1 & 24 \\
\hline & 100 & 0.77 & 0.20 & 0.84 & 2 & 1 & 11 \\
\hline ANOVA & & \multicolumn{6}{|c|}{$P>\mathrm{F}$ value } \\
\hline \multicolumn{8}{|l|}{ Malus trilobata } \\
\hline Source (S) & & $\mathrm{NS}^{\mathrm{y}}$ & NS & NS & NS & NS & NS \\
\hline Fertilizer rate $(\mathrm{FR})$ & & NS & NS & NS & NS & NS & $* *$ \\
\hline $\mathrm{S} * \mathrm{FR}$ & & NS & NS & NS & NS & NS & NS \\
\hline \multicolumn{8}{|l|}{ Acer syriacum } \\
\hline Fertilizer rate (FR) & & NS & NS & NS & NS & NS & NS \\
\hline
\end{tabular}

${ }^{\mathrm{z}}$ Each value is the mean of three plants for each source and fertilizer rate.

${ }_{\mathrm{NS}}, *$, and $* *$ indicate no statistical difference at $\alpha=0.05$ level of significance or statistical difference at $\alpha \leq 0.05$ or $\alpha \leq 0.01$, respectively.

Table 9. Whole plant $\mathrm{N}-\mathrm{P}-\mathrm{K}$ ratios (expressed relative to $\mathrm{P}$ ) of seedlings raised from two Malus trilobata trees and one Acer syriacum tree when grown under either 25 or $100 \mathrm{mg} \cdot \mathrm{L}^{-1}$ $\mathrm{N}$ water-soluble fertilizer.

\begin{tabular}{lcccc}
\hline & $\begin{array}{c}\text { Fertilizer rate } \\
\text { Source }\end{array}$ & \multicolumn{3}{c}{ Ratio } \\
\cline { 3 - 5 }$\left(\mathrm{mg} \cdot \mathrm{L}^{-1} \mathrm{~N}\right)$ & $\mathrm{N}$ & $\mathrm{P}$ & $\mathrm{K}$ \\
\hline MT 2 & 25 & $5.7^{\mathrm{z}}$ & 1 & 6.8 \\
& 100 & 7.7 & 1 & 5.5 \\
MT 3 & 25 & 7.3 & 1 & 8.8 \\
& 100 & 7.9 & 1 & 7.7 \\
AS 2 & 25 & 5.2 & 1 & 6.1 \\
& 100 & 4.5 & 1 & 5.0 \\
\hline
\end{tabular}

${ }^{\mathrm{z}}$ Each value is the mean of three plants per source and fertilizer treatment.

in the shoot system. The relative percentage of Malus shoot dry weight was high compared with North American Quercus (oak) species, Malus 'Prairifire' (Prairifire crabapple), Acer rubrum 'Autumn Blaze'(Autumn Blaze red maple), and Nyssa sylvatica (Black gum) plants grown under similar conditions (Drunasky and Struve, 2005; Larimer and Struve, 2002; Stoven, 2004; Struve, 1995). The relative percentage of Acer syriacum shoot dry weight was similar to Cercis canadensis and C. siliquastrum (judas tree), Acer rubrum 'Autumn Blaze', Malus 'Prairifire', and Quercus prinus (chestnut oak) (Drunasky and Struve, 2005; Larimer and Struve, 2002; Stoven, 2004; Zahreddine et al., 2007a). The significance of the relatively high Malus trilobata stem dry weight is unknown.

Nitrogen loading occurred in the Malus trilobata plants grown at the high fertilizer rate, but not in Acer syriacum seedlings (Table 5). Nutrient loading is defined as an increase in plant tissue nutrient concentration without a significant increase in plant dry weight (Malik and Timmer, 1995). Nutrient loading was observed in Cercis siliquastrum sources grown at $100 \mathrm{mg} \cdot \mathrm{L}^{-1} \mathrm{~N}$ in a study by Zahreddine et al. (2007a). Studies by Xu and Timmer (1999) and by Malik and Timmer (1995) showed that nutrient-loaded conifer seedlings performed better when outplanted in nutrient-poor sites than those not nutrientloaded. In addition, nutrient loading increases the competitive ability for resources of the crop species in weed-prone or heavily vegetated sites (Malik and Timmer, 1995), which could be useful for conservation purposes (reforestation or reintroduction of species to their native habitats). The possible benefits of nutrient loading nursery stock during production in Malus trilobata plants require experimental confirmation. If these benefits are proven, nursery managers could offer higher-quality plants, assuming the benefits of nutrient loading are not offset by decreased plant quality (i.e., smaller caliper, smaller total plant dry weight, and higher shoot to root ratio).

Similar to Cercis siliquastrum (Zahreddine et al., 2007a), neither mineral nutrient uptake nor mineral nutrient uptake efficiency between May and September were affected by fertilizer rate in Malus trilobata and Acer syriacum seedlings (Table 8). Nutrient contents of Malus trilobata seedlings were similar under the two fertilizer rates because although seedlings had higher dry weights at the lower fertilizer rate, nutrient concentrations were lower than for those grown at the high rate.

Although comparisons are limited, nitrogen use efficiency of both species was lower at the higher fertilizer rate in this study and others (Table 8; Larimer and Struve, 2002; Struve, 1995; Zahreddine et al., 2007a). Nitrogen use efficiency ranged between $7 \%$ and $11 \%$ in Malus and $3 \%$ and 5\% in Acer compared with a range of $7 \%$ to $15 \%$ in Cercis siliquastrum (Zahreddine et al., 2007a). Also similar to Cercis siliquastrum, $\mathrm{P}$ use efficiency in Malus trilobata and Acer syriacum was lower than $\mathrm{N}$ and $\mathrm{K}$ use efficiencies. Phosphorus use efficiency at both fertilizer rates ranged between $1 \%$ and $2 \%$ in Malus trilobata and $1 \%$ in Acer syriacum; in Cercis siliquastrum, phosphorus use efficiency was $2 \%$ to $4 \%$.

Similarly, potassium use efficiency in Malus trilobata was lower at the high fertilizer rate than at the low fertilizer rate and was higher than nitrogen use efficiency or phosphorus use efficiency. It should be noted that at the low fertilizer rate, the compost contributed $85 \%, 88 \%$, and $94 \%$; and at the high rate, it contributed $58 \%, 95 \%$, and $76 \%$ of the total N, P, and $\mathrm{K}$ applied to the plants, which contributed to the relatively low nutrient use efficiency. Plants under the low fertigation regime $\left(25 \mathrm{mg} \cdot \mathrm{L}^{-1} \mathrm{~N}\right)$ received $3.3,0.5$, and $0.8 \mathrm{~g} \mathrm{~N}, \mathrm{P}$, and $\mathrm{K}$, respectively, between 12 May and 24 Sept.; those under the high fertigation regime $\left(100 \mathrm{mg} \cdot \mathrm{L}^{-1} \mathrm{~N}\right)$ received 13.3, 2.0, and $3.2 \mathrm{~g} \mathrm{~N}, \mathrm{P}$, and $\mathrm{K}$. respectively. Comtil alone supplied 18.0, 39.8, and $9.9 \mathrm{~g} \mathrm{~N}$, $\mathrm{P}$, and $\mathrm{K}$, respectively, during the growing season. An explanation for the high K efficiency could be genetic ability of Malus trilobata to store $\mathrm{K}$ for to be used in osmotic adjustment during drought. Deficiency in $\mathrm{K}$ has been associated with reduced ability to withstand stress and maintain high transpiration rates (Tisdale et al., 1998). Another possible explanation for why potassium use efficiency was higher than nitrogen use efficiency and phosphorus use efficiency maybe that $\mathrm{K}$ promotes the conversion of inorganic $\mathrm{P}$ to nucleic acids and phosphoproteins that would otherwise cause plant toxicity. Toxicity effects resulting from elevated inorganic phosphates has been reported in Ilex crenata when $\mathrm{P}$ was applied at concentrations higher than 10 ppm (Wright and Niemiera, 1987).

The fertilizer used in this study had an $\mathrm{N}-$ $\mathrm{P}-\mathrm{K}$ ratio of $6.8-1-1.6$ when $\mathrm{N}$ and $\mathrm{K}$ were expressed relative to $\mathrm{P}$. However, whole plant mineral nutrient ratios at the end of the growing season did not match the fertilizer $\mathrm{N}-\mathrm{P}-\mathrm{K}$ ratios. Plant tissue contained more $\mathrm{N}$ than $\mathrm{P}$ or $\mathrm{K}$ under the high fertilizer rate, but $\mathrm{K}$ content was highest when plants were grown at the low fertilizer rate. This was true for both species. Nutrient use efficiency can be increased by matching the fertilizer nutrient ratio to plant $\mathrm{N}-\mathrm{P}-\mathrm{K}$ tissue ratios.

There were differences in growth between the two Malus trilobata sources as there was among six Cercis siliquastrum sources (Zahreddine et al., 2007a). Malus trilobata, like other apple species, is reported to be crosspollinated by insects (http://www.ibiblio. org/pfaf/cgi-bin/arr_html?Malus+trilobata\& CAN=LATIND). Although both mother trees of Malus trilobata came from the same stand, there were significant differences in growth between the half-sib families. However, there were no differences among the Malus trilobata sources in mineral nutrient uptake efficiency or mineral nutrient partitioning, but there were significant differences among the six Cercis siliquastrum sources in N, P, and $\mathrm{K}$ concentrations and contents (Zahreddine et al., 2007a). Interestingly, whole plant tissue from MT3 contained more $\mathrm{N}$ and $\mathrm{K}$ than MT2 tissue at both fertilizer rates. The $\mathrm{N}-\mathrm{P}-\mathrm{K}$ ratio of MT3 was 7.6-1-8.25 compared with that of MT2, which was equal to 6.7-1-6.15.

As was previously mentioned, Malus trilobata is endemic to Lebanon and is endangered, whereas Acer syriacum's wood is often used by local people for firewood and 
cabinet making. These species have an economic potential as a result of their ornamental attributes. One way to conserve them is by encouraging the establishment of ex situ facilities and in situ conservation efforts. Establishing botanic gardens, seed banks in Lebanon, or conserving entire ecosystems by turning them into "protected areas" will require an extensive amount of time, research effort, and huge capital. A more practical and feasible alternative will be to encourage the cultivation of the species. Cultivation practices will satisfy both commercial and conservation purposes. Nursery managers can introduce both species into the Lebanese landscape market by propagating seedlings and selling them to local municipalities for street plantings and to people who want to plant those trees in their home gardens. Encouraging the cultivation of native trees will also reduce the dependence of the local market on introduced landscape species; it will also reduce the potential of introducing non-native pests and pathogens that negatively affect the environment. Moreover, reintroducing the trees into their native habitats and other reforestation projects will take place once those trees are made available in the market.

\section{Conclusions}

Acer syriacum and Malus trilobata seedlings are amenable to container production. Seedlings of both species can be grown at 25 $\mathrm{mg} \cdot \mathrm{L}^{-1} \mathrm{~N}$ using $21 \mathrm{~N}-3.1 \mathrm{P}-5.9 \mathrm{~K}$ water-soluble fertilizer. Additional fertilizer rates need to be tested to determine the optimum fertilizer rate. Nutrient uptake was unaffected by fertilizer rate in Malus trilobata and Acer syriacum, but $\mathrm{N}$ concentration in Malus trilobata was. Nitrogen loading occurred in Malus trilobata plants grown under the high fertilizer rate, but any possible benefits need to be confirmed by field trials to determine whether the nutrient-loading benefits out- weigh the decrease in plant quality (smaller plants and lower dry weights). There were significant differences in growth between the two Malus trilobata half-sib families although both trees were growing in the same stand. We recommend that seeds be collected from additional tree sources for both species and tested for growth and nutrient partitioning under container production to identify genetically superior seed trees of these threatened species. Container nursery production and transplanting to managed landscapes might be a practical ex situ genetic conservation method.

\section{Literature Cited}

Anonymous. 1999. Les Principaux Arbres du Liban: La Fascicule des Essences Forestieres du Liban. Projet d'assistance a la protection de la couverture vegetale au Liban. Ministry of Agriculture and European Union.

Drunasky, N. and D.K. Struve. 2005. Quercus macrocarpa and $Q$. prinus physiological and morphological responses to drought stress and their potential for urban forestry. Urban For. and Urban Greening. 4:13-22.

Evans, G.C. 1972. The quantitative analysis of plant growth. Blackwell Scientific, Oxford, UK.

Gilliam, C.H., G.S. Cobb, and C.E. Evans. 1984. Effects of nitrogen concentration and container size on growth of Pyrus calleryana 'Bradford'. J. Enviro. Hort. 2:53-56.

Gilliam, C.H., S.M. Still, S. Moor, and M.E. Watson. 1980. Effects of three nitrogen levels on container-grown Acer rubrum. HortScience 15:641-642.

Hillier and Sons. 1973. Manual of trees and shrubs. Hillier and Sons, Winchester, UK.

Ingestad, T. 1979. Nitrogen stress in Birch seedlings. II. N, K, P, Ca, and $\mathrm{Mg}$ nutrition. Physiol. Plant. 45:149-157.

Jull, L.G., S.L. Warren, and F.A. Blazich. 1994. Nitrogen nutrition of containerized Cryptomeria japonica 'Elegans Aurea'. J. Environ. Hort. 12:212-215

Larimer, J. and D. Struve. 2002. Growth, dry weight and nitrogen distribution of red oak and 'Autumn Flame' red maple under different fertility levels. J. Environ. Hort. 20:28-35.

Lumis, G., P. Purvis, and L. Taurins. 2000. Flood irrigation of container-grown Euonymus and Thuja as affected by fertilizer rate and substrate. J. Environ. Hort. 18:13-17.

Malik, V. and V.R. Timmer. 1995. Interaction of nutrient-loaded black spruce seedlings with neighboring vegetation in greenhouse environments. C. J. For. Res. 25:1017-1023.

Mouterde, P. 1966. Flore Du Liban et De La Syrie. Vol. 1. Imprimerie Catholique, Beirut, Lebanon.

Mouterde, P. 1970. Flore Du Liban et De La Syrie. Vol. 2. Imprimerie Catholique, Beirut, Lebanon.

Musselwhite, S., R. Harris, and R. Wright. 2004. Fertilizer requirements for container-grown Buxus spp. J. Environ. Hort. 22:50-54.

Stoven, A. 2004. Development of an Ohio tree liner production system using retractable-roof greenhouses. Graduate School of The Ohio State University. MSc Thesis.

Struve, D.K. 1995. Nitrogen, phosphorus and potassium recovery of container-grown red oak and blackgum seedlings under different fertilizer application methods. J. Environ. Hort. 13:169-175.

Stubbs, H.L., S.L. Warren, F.A. Blazich, and T.G. Ranney. 1997. Nitrogen nutrition of containerized Cupressus arizonica var. glabra 'Carolina Sapphire'. J. Environ. Hort. 15:80-83.

Tisdale, S.L., W.L. Nelson, J.D. Beaton, and JL. Havlin. 1998. Soil fertility and fertilizers. Macmillan Publishing Co., New York, NY.

UNEP. 1996. Biological diversity of Lebanon. Ministry of Agriculture of Lebanon vol 9, 255 p.

Wright, R.D. and A. Niemiera. 1987. Nutrition of container-grown woody nursery crops. Hort. Rev. (Amer. Soc. Hort. Sci.) 9:75-101.

$\mathrm{Xu}, \mathrm{X}$. and V.R. Timmer. 1999. Growth and nitrogen nutrition of Chinese fir seedlings exposed to nutrient loading and fertilization. Plant and Soil 216:83-91.

Zahreddine, H.G., D.K. Struve, and S. Talhouk. 2007a. Growth and nutrient partitioning of containerized Cercis siliquastrum L. under two fertilizer regimes. Scientia Hort 112(1):80-88.

Zahreddine, H.G., D.J. Barker, M.F. Quigley, K. Sleem, and D.K. Struve. 2007b. Patterns of woody plant species diversity in Lebanon as affected by climatic and soil properties. Lebanese Science Journal 8:21-44. 